\title{
Forest educators as bearers and implementers of deep ecology ideas
}

\author{
Karolina Macháčková \\ Czech University of Life Sciences Prague, Faculty of Forestry and Wood Sciences, Kamýcká 129, CZ - 165 00, Praha 6 - Suchdol, \\ Czech Republic
}

\begin{abstract}
People think very little about the consequences of consumer and ecological manners. Responsibility for raising children to sustainable behaviour is transmitted to educational institutions that bear the full weight of this burden. Nonteaching experts such as foresters enter the educational process. These specialists are called "forest educators". At the 14th European Forest Pedagogics Congress 2019 in Latvia, 167 forest educators from Europe met, and 52 of them were willing to participate in a qualitative research survey. This paper aimed to identify why foresters, as people without pedagogical education and despite the unfavourable funding, become educators. The following questions guided this research: What leads them to start organizing educational and adventure programmes for children and the public? Is their intrinsic motivation based on an unconscious level to implement ideas of Deep Ecology? Philosophy of Arne Naess and semi-structured interviews with forest educators in the form of the Pyramid Model of Wengraf, through which qualitative data were obtained, methodologically approached this paper. Interviews with foresters revealed their values, needs, motivation, dominant psychological-ethical moments and prosocial behaviour that brings inner satisfaction and pedagogical activity as an added value of their profession. Forest educators have a unique philosophical system related to nature and the environment. They subconsciously follow and develop the ideas of Deep Ecology through the methods of Forest Pedagogy. The paper presents the way of involving forest educators into the distance and online teaching due to the Coronavirus pandemic, as well as the topic for further research in this area.
\end{abstract}

Key words: Arne Naess; ecosophy; education for the 21st century; Forest Pedagogy online; Wengraf Pyramid model

Editor: Bohdan Konôpka

\section{Introduction}

The cause of the ecological crisis is due to human attitudes of superiority over nature. The creation of a new harmonious relationship between humans and nature is the goal for a deeply oriented environmental movement, which is associated with the name of the Norwegian philosopher Arne Naess (1912-2009), who considers his ideas as "nonviolent and long-lasting revolution" (Naess 1989, 1993). It seems time has come to resurrect and bring to mind the ideas of Arne Naess, who gave the world a coherent philosophy and the necessary dose of radicality. His appeal seems to be up to date these days.

Modern society is harming the environment. The Value Objectivism characterizes Deep Ecology: animals have value in themselves and the right to live, even though they are not directly useful to humans. Naess (1989) accentuates a universally shared lifestyle that is sustainable without injuring other life forms. Arne Naess's ideas can be well applied in education for the 21st century, which must reflect current global challenges such as cli- mate changes, global economic stability, labour market trends, impending energy crisis, depletion of non-renewable fossil fuels, poverty, and inadequate medical care (Bolstad et al. 2012). Slaughter (1974) states that the long-term intention of the educational system must concern broader social, political, and economic objectives.

Education is the key to make society move towards sustainable and ecological perception (Britto 2017). Dumont et al. (2010) introduce seven principles of learning and teaching for the 21st century. Main pillars are (1) Learners at the centre; (2) The social nature of learning; (3) Emotions are integral to the learning process; (4) Recognizing individual differences; (5) Stretching all students; (6) Assessment for learning; (7) Building horizontal connection. It is precisely the point (3), intuition, emotionality, and empathy, thanks to which, according to Naess (1989), the individual acquires the truth about the world and wisdom.

Naess (1989) considers nature as the best source of knowledge; however, the disadvantage of many environmental education programmes is that they show nature 
from an adult perspective, which is too abstracted for the child's perception in the early years. Naess suggests that the essential tool for the knowledge of nature is the non-rational form of cognition, empathy, identification through emotions, not through reason. Humans perceive nature by empathy more objectively than scientifically. That is the reason why education should consist of events and creative activities; there is not a sharp line between learning and action (Naess 1989, 1993). How we relate to nature is a matter of feeling, so Naess recommends getting feelings into learning as well and emphasizes that feelings have cognitive value (Devall \& Sessions 2007). This point of view is supported by Wedlichová (2011): sensory experiences can increase emotional intelligence in children.

Environmental education and training for sustainable behaviour are closely related to the natural environment. We can hardly find a better example of sustainable management for centuries than in forestry. In nature, it is the best to demonstrate methods to improve sustainable development and environmental education. Slee (2001) considers forest to be a natural framework, essential for human existence and development as forests perform many functions-protective, medicinal, economic, recreational, and educational. Could it be the reason why foresters enter the educational process?

Forest Pedagogy represents neoteric sustainability education that corresponds to the philosophy of Deep Ecology, affecting emotions, will, and awareness. The basic principle of Forest Pedagogy is the perception of nature by all senses, according to Pestalozzi's concept of "learning with head, heart, and hand" (Kuhlemann \& Brühlmeier 2002). Cornell (1991, 1998, 2012) qualifies Forest Pedagogy as a form of public relations and social phenomenon that includes environmental education, institutions, associations, forest schools and describes four levels of experience: awakening enthusiasm, focusing attention, direct experience, and sharing inspiration.

The term "forest educator" is currently used and unified in the international forest environment and means a Forest Pedagogy Lecturer as a professional forester with pedagogical education gained by a particular course. Experts with forestry education or experience in forestry who have completed a Forest Pedagogy course accredited by the relevant Ministry of Agriculture of the given state can become forest educators. Forest Pedagogy courses are of two types and take 40 hours each. The introductory one, where foresters learn the fundamentals of pedagogy, psychology and didactics, and are trained to work with class groups of kindergartens, primary and secondary schools. The advanced course is intended for graduates of the introductory course and expands the target groups by adults, seniors and groups with special educational needs. Forest Pedagogy courses are compatible with courses in other European countries and are based on the outputs of the European project PAWS (Pädagogische Arbeit im Wald).
The common goal of foresters and teachers should be to organize a lesson in which pupils better understand the context of nature. The forest would serve as a unique classroom, combining the experience of the forester with the teacher's expertise. This approach connects pedagogy-experience and nature (Machar 2009), where pupils meet their teachers working as a team member and gain valuable social experience. Stern et al. (2010) revealed that specific characteristics of teachers, particularly enthusiasm, interest in the matter, sincerity and charisma, are strongly associated with more positive pupils achievements. Other authors support the importance of demonstrating genuine care of students (Russel 2000; Ballantyne et al. 2001; Fien \& Packer 2001) and providing a holistic experience (Tilden 1957; Skibins et al. 2012). Stern et al. (2008) found that when teachers are actively involved in on-site lessons with instructors, students' outcomes are generally more positive. The findings suggest that teachers and other adults play a crucial role in environmental literacy development (Emmons 1997; Rickinson 2001; Sivek 2002; Stern et al. 2008, 2010).

Increasing aggression of children and heavy mental burden accompany the educational process. Children are alienated from nature, showing no interest in education (Mazáčová 2001; Bajtoš \& Honzíková 2007). Burnout often occurs in the teaching profession, and the education sector is often under-funded in many countries. Liu et al. (2000) reported that in the USA teaching is a significantly less prestigious profession than others in terms of income, with teachers earning among the lowest annual salaries of their college cohort (Henke et al. 2000, as cited in Liu et al. 2000). Teachers work under the scrutiny of parents and the media without sufficient job satisfaction (Spear et al. 2000; Lai et al. 2001; Hoyle 2008). Much of the existing literature on teachers' motivation to teach coming from western countries found teachers to be motivated mainly by intrinsic and altruistic motives such as nurturing students' growth (Sinclair 2008). They believe they contribute to society and may consider teaching as a vocation (Spear et al. 2000; Scott et al. 2001; Richardson \& Watt 2006; Alexander 2008).

This paper aims to identify why foresters, as people without pedagogical education and despite the unfavourable financial valuation, become educators. The following questions guided the research: What made them start organizing educational and adventure programmes? Is their intrinsic motivation based on an unconscious level to implement ideas of Deep Ecology? Semi-structured interviews methodologically approached this topic with forest educators in the form of the Pyramid Model of Wengraf, through which qualitative data were obtained.

The results may contribute to understanding better the content of work, formal and legal issues as well as employment conditions of forest educators and improve their relations with teachers. Education is an integral part of forestry, in particular as forest tenure changes, and now the share of private forest ownership is large. The 
growing public interest in the recreational function of the forest makes forest education now more crucial than ever.

\section{Material and methods}

In recent years, there has been an increase in new criteria to assess the quality of qualitative research. In a plethora of modern terms, many modern concepts can be found such as imperial validity, ironic validity, situational validity, neopragmatism validity, rhizomatic validity, overt validity, instrumental validity, or theoretical validity (Altheide \& Johnson 1994). Based on the above, the qualitative research was carried out, as qualitative data naturally describe the situation and aims to understand people and the events in their lives (Gavora 2008). The interviewee fully expresses subjective opinions and indicates relations and contexts (Hendl 2016). Qualitative research is not based on any hypothesis or theory but tries to outline a new theory (Švaříček \& Šed'ová 2007). The advantage of the interview is also a significantly higher proportion of completed interviews compared to the return rate of the questionnaires, and also the possibility to clarify responses which have not been previously appropriately understood and the researcher is sure to speak to the intended person (Disman 2002). In this paper, the method of the in-depth individual semi-structured interview was applied. The Pyramid Model of the interview was used to create the interview scheme (Wengraf 2001). This model consisted of a central research question, theory questions, and particular interview questions.

\subsection{Research sample}

The first criterion was that all of the respondents for qualitative research were forest educators actively pursuing their profession. The second criterion was an international comparison. An available opportunity was the 14th European Forest Pedagogics Congress 2019 in Riga, Latvia, with international participation of one hundred sixty-seven forest educators from eighteen European countries. The third criterion was the diversity of organizations in which forest educators operate, i.e. Urban or State Forests, Forest Learning Centers, Environmental Centers, and Youth Homes.

The research sample included fifty-two active forest educators from various forestry organizations from five regions of the Czech Republic (18), as well as foresters from Finland (2), Norway (3), Latvia (9), Germany (5), Poland (3), Slovakia (4), Slovenia (3), Luxembourg (5) and other countries. The qualitative data collection was in progress from 1st July to 31st October 2019 during the congress, and after its completion, interviews with forest educators took place via Google Meet and Microsoft Teams online. Subsequently, the text was submitted to the respondents for authorization.
The structure of questions according to the Pyramid Wengraf model (2001) is as follows:

\section{The main research question}

What made foresters become educators, what does the profession bring to them and what motivates them?

\section{Specific Research Question 1}

What work experience and education did the foresters have before they become educators?

- Forestry education,

- pedagogical education,

- previous experience from leisure activities.

\section{Specific Research Question 2}

What influenced the decision of the forest educator to choose his new professional focus?

- Previous positions,

- financial remuneration,

- other reasons.

\section{Specific Research Question 3}

How do forest educators perceive their profession?

- Positives and negatives,

- how should ideal forest educator look like?

Probing, based on questions and non-verbal hints, was used to deepen answers in a particular direction. A problem-oriented interview, tailored to the research goal was conducted. Transcripts of interviews were transformed and interpreted to capture the complexity of the examined phenomenon. The Open coding for data evaluation and the ATLAS.ti programmes were used, where each significant sentence, word, or phrase, was highlighted and assigned a code representing the essence of the text. According to the codes, information was compared to each other, merging and integrating similar and related semantic units.

\section{Results}

On the answers obtained from the interviews conducted according to the Pyramid Model by Wengraf (2001), data were analyzed and interpreted.

\subsection{Education and professional experience of forest educators}

\subsubsection{Forest Education}

Almost all (49) forest educators addressed have a forestry education and completed a course in Forest Pedagogy, which is an essential condition for practising this profession. A minimal number of foresters (3) do not have a forestry education, which is compensated by no less than ten years of experience in environmental education centres. 


\subsubsection{Pedagogical education}

All respondents (52) are graduates at least an introductory Forest Pedagogy course. More than half of them (38) also have a certificate from the extension course. Everyone confirms that the course is beneficial, as they know the basics of didactics, psychology, have the opportunity to meet new colleagues and acquire inspiration for future work. Forest educators mostly agree that without the basics of developmental psychology and the basics of pedagogy, I would probably not know how to engage children. Sixteen foresters already have a bachelor's pedagogical education obtained in college. Four of them are currently studying vocational subjects or leisure-time education. Foresters who are interested in further pedagogical education are those for whom Forest Pedagogy takes up more than half of their working time. Foresters who provide Forest Pedagogy activities beyond their work duties, do not consider the further pedagogical study. However, they all agree that the basics of pedagogy, psychology, and didactics are desirable. Otherwise, this would affect the quality of the programmes.

\subsubsection{Free-time pedagogy}

Most forest educators have been interested in nature, experiential education, and children since their youth, as head of children's camps, Scout, or another organization. One answer for all:As a child, I liked going to summer camps in the countryside, and I am glad that I can bring this hobby to myjob as well. Most of the respondents (46) have tacit knowledge in organizing leisure and free-time activities.

\subsection{What influenced the decision to become a forest educator}

Only a third of the foresters (17) carried out this activity on a full-time basis and had to leave their existing post. The others focus on the main content of the work, such as forest recreational function, forest protection, or forest management, so their pedagogical activities take up only part of their working time. Respondents often spend free time preparing Forest Pedagogy activities and do it beyond their job, in many cases for free or for a symbolic allowance only. Especially the statements of the Czech and Slovak forest educators show that the management of forest enterprises prefers non-pedagogical content of work.

\subsubsection{Previous employment}

The previous job position remains, and educational activity is included in addition. The scenario prevails, where foresters participated in environmental and leisure activities (Scout, Forest Pedagogy course) and the supervisor then offered them the opportunity to attend the course and become a forest educator.

\subsubsection{Financial aspect}

Forest educators coincide that salaries did not play a role in their decision-making. One forest educator describes it as follows: It is not possible to get rich in Forest Pedagogy. When it becomes a business, enthusiasm is lost. At present, in many European countries, the profession of a forest educator is not well-paid for generating a separate full income. Thanks to these facts, it is not appropriate to expect the forester to perceive Forest Pedagogy as a profession, but rather as a hobby, especially in the postcommunist countries where Forest Pedagogy does not have such a tradition.

\subsubsection{Raison d'etre for Forest Pedagogy}

The vast majority of forest educators say this is due to the variety and creativity of their profession. They praise not to have office work, duties are diverse, and the job brings satisfaction. There are considerable differences between countries.

Forest educators from Austria state that although in their country forest education courses are open to all interested, only a graduate with forestry education receive the certificate and only the certificate holder can be financially supported.

Polish forest educators report that at least one fulltime forest educator is available at each forest administration in Poland and offers four follow-up programmes for each season. The average Polish Baccalaureate attends, on average, thirty Forest Pedagogy lessons. It may affect young people in the future on Forest Pedagogy.

Estonians are considered "forest nation" and want to raise awareness about the forest among the public, especially in preschool children, and find many candidates interested during the Forest Weeks.

Foresters from Finland are also motivated by material reasons: there are many forest owners in Finland, and every sixth schoolchild is expected to own the forest in the future, so children should be informed about it. To educate the schoolchild, efforts to engage teachers and so the Finnish Forestry Association, together with teachers, created publications and websites to support teaching at schools.

The situation in the Czech Republic is significantly different. Afrequently mentioned reason for forest educators from the Czech Republic is the possibility to "clarify" the forestry and forester's reputation negatively affected by media and to provide nature-oriented upbringing and awareness-raising. Forest Pedagogy is one of the ways to attract people to the forest and also to improve the image of forestry. A curious reason for being a forest educator was mentioned by one female, who received the answer to the question: "Who is the most significant pest in the 
forest?" Answer: Forester. It was precisely the moment when she decided to change the image of forestry in the eyes of the general public in the Czech Republic.

\subsection{Perception of Forest Pedagogy}

Distinctions between countries are evident. Each forest educator devotes to Forest Pedagogy and educational programmes in another way and has different time and financial support, which are based on how a particular forestry enterprise approaches Forest Pedagogy.

\subsubsection{Pros and Cons of Forest Pedagogy}

All respondents agreed that the most considerable advantage of Forest Pedagogy is the possibility to get people into the countryside, to familiarize them with the forest environment, what is in line with Forest Pedagogy goals (Harkabus \& Marušáková 2007). Forest educators can arrange the programmes, be it a theme, games, activities, or a place to go and appreciate having contact with new people and the possibility of self-education, socialization, and self-realization. They mostly appreciate attending seminars, lectures, and meetings organized for forest educators where they can learn and inspire. Young female forest educators expect to gain experience and skills in activities with children in nature, which they can use in raising their kids. They see what today-kids are missing.

Half of the forest educators prepare programmes and materials during free time. Almost half of the respondents regret not to have sufficient financial or moral support at their employers. Forest educators, especially from the former post-communist states, repeatedly complained that the public does not appreciate their work and considers it inferior. Many professional foresters look at their colleagues with absolute disrespect. They consider Forest Pedagogy to be entertainment only. Another disadvantage is that forest educator has no chance to get to know the children accurately in a short period, and cannot cooperate with them in contrast to regular leisure activities or school lessons.

To respond to the question of whether the foresters lost something in carrying out their educational activities, embarrassing answers were received. Some admit that this activity deprives them of illusions, mainly of teachers' cooperation with them and how some teachers treat children and foresters. Following are presented the words of one forester: I think that teachers are afraid to "hand over" their pupils to us as if they are afraid of losing control and power. Sometimes the teacher comes in a bad mood, and his current mental state is unfortunately passed on to children. They are then bored, and it is complicated to master the discipline. This experience was repeated: When several classes came at the same time, the teachers stood apart and talked among themselves and showed no interest in the pupils. I was then very disappointed that the teachers wrote a critical assessment, not even knowing what was happening around. Many forest educators have lost their expectations about the basic knowledge of the public about forest and nature and the respect that people should have for nature.

\subsubsection{The idea of an ideal forest educator}

The final question of the interview concerns the characteristics, abilities, experience, and education of ideal forest educator should have. Two streams of opinion emerge from the respondents' answers. Twenty-seven would appreciate practising Forest Pedagogy at full-time: I would have time to refresh content, innovate games, have more scope and support. Collaboration with schools could be planned and implemented in the long term without the risk of any other event interfering with the plan.

However, the other half (25) of forest educators strongly disagree with this and believe that foresters should only do this part-time. They are satisfied that they do not have to do educational plans every day and are engaged in other activities, and Forest Pedagogy does not become a routine matter. There is also an opinion that: Foresteducator is not an independent profession and should not be in the future. It is something in addition to the professional forest focus.

\section{Discussion}

Forest educators are introduced as professional foresters with pedagogical education gained by a particular course (Cornell 1991; Bolay \& Reichle 2007). There is no relevant article or study that would examine in more detail the reasons and motives of foresters, why they voluntarily and despite the low funding undertake pedagogical courses so that they can act as teachers of their kind.

The paper aimed to identify why foresters enter the educational process and if their intrinsic motivation is based on the subconscious level of Deep Ecology thinking. Interviews showed that foresters have a specific personal framework of values related to human and nature issues. For forest educators, ecology is not just a theory but a deep conviction. They are probably not even aware, their stance to life reflects a deep ecological feeling that has roots in A. Naesse's conception. Forest educators try to pass on the depth of knowledge and experience, live in nature and with nature, not just visit it. They show the public how to move in the forest without consequences, respecting all life forms, not just those beautiful, remarkable, or useful. They teach not to use living beings only as a resource; leading to the recognition of their intrinsic value. Forest educators protect the forest ecosystem as a whole, not just individual life forms and show that people living in urban areas can be connected with nature even in a disturbed environment, as parts of green can be found everywhere. The ideas of Deep Ecology are based on these rudiments (Naess 1989, 1993).

Why do foresters engage in education despite many obstacles, misunderstandings and inadequate funding? 
One of the reasons is the general effort of foresters to explain objectively the distorted information disseminated by the media relating the bark beetle calamity. All the foresters addressed agree that they have the honour to carry out highly professional activities for nature and future generations and do it with enthusiasm, even if the result of their effort is difficult to measure. Foresters believe their activities have a deeper meaning. Interest, a positive attitude to nature, and self-realization force them to go forward. Their job offers an opportunity for the initiative, responsibility, and knowledge growth. Foresters consider their calling essential and are willing to devote to it, although they often do not get extra money for their endeavour. Theprofession of foresteducatorhasapsychological-ethical moment-the chance to educate someone else is perceived as a reward. Forest educators consider as a substantial intrinsic value of the job to broaden horizons for someone else and to expand the moral compass. The above is consistent with the motives of intrinsic motivation presented by Dieblová (2005).

Forest educators understand the context of nature very well, their tacit knowledge goes beyond school textbooks of natural history, and they could be a functional link between the public and the natural ecosystem. Based on strong inner convictions and enthusiasm, it is recommended to involve them in school curricula to provide transmission of knowledge and experience to children. The content of School Education Programmes can be arranged in the school curriculum in coherent parts, such as modules or blocks using parallel support by close cooperation with a local forest centre.

The Coronavirus pandemic increases the demands on the form and methodology of teaching. The Ministries of Education of the affected states now more recommend including full-time educational activities held in the school garden, playground, park and school surroundings, where there is no accumulation of more people in order to reduce epidemiological risks, improve the overall health, concentration and well-being of pupils and teachers. Many parents and teachers perceive outdoor learning as too risky and unsafe. The presence of a forest educator, as an expert on a stay in nature, should eliminate the concerns of parents.

In pandemically affected areas, pupils are not present at school and are educated synchronously and asynchronously. There is also a new dimension for the online inclusion of forest educators into the teaching process of those subjects that have nature and science as a basis. A forest educator wearing a livery can engage children with his demeanour, speech, personal example, positive attitude and commitment. The forest-dressed educator does not fit into uniformity of civilian teachers and can pass on knowledge and context of a different dimension than the science teacher could. Forest Pedagogy methods can also be manifested in the distance form; the forest educator assigns tasks, for which pupils have to get out in nature and together with their classmates in the online forum share their experiences of the forest. The growing ability to recognize the signs of upcoming changes in the forest that children would report to the forester could be regarded as an added value. The looming negative phenomena in the forest can thus be identified and resolved at the beginning. Even if only one child is enthusiastic about this idea, it would be a significant help to foresters, who, due to the scale of their activities, may not always be able to detect all changes in their district immediately. This way of teaching could help and solve the problem even for teachers who do not support outdoor activities.

\section{Conclusion}

Involving professionals into education is desirable and beneficial-due to the differences between learning about versus learning from an expert (Berliner 2001; Guskey \& Yoon 2009). Children are not passive recipients only, they are often the initiators of new manners, and by constituting their relationship to nature, it is realistic to expect the effect that is secondarily transmitted on parents.

The involvement of forest educators in distance teaching will be the theme of further research survey, where the Experimental group (online tuition with forest educator) would be compared with the Control group (distance education by the teacher) through a didactic test.

\section{Acknowledgements}

A warm thanks to the forest educators for their willingness and patience to answer the questions.

\section{References}

Alexander, P.A., 2008: Charting the course for the teaching profession: The energizing and sustaining role of motivational forces. Learning \& Instruction, 18: 483-491.

Altheide, D. L., Johnson, J. M., 1994: Criteria for assessing interpretive validity in qualitative research. In: Denzin, N. K., Lincoln, Y.S. (eds.): Handbook of qualitative research. Thousand Oaks, Sage, p. 485-499.

Bajtoš, J., Honzíkova, J., 2007:Vybrané statě školní pedagogiky. Plzeň, Západočeská univerzita v Plzni., 192 p.

Ballantyne, R., J. Fien., J. Packer., 2001: School Environmental Education Programmesme Impacts upon Student and Family Learning: A Case Study Analysis. Environmental Education Research, 7:23-37.

Berliner, D. C., 2001: Learning about and learning from expert teachers. International Journal of Educational Research, 35:463-482.

Bolay, E., Reichle, B., 2007: Waldpädagogik. Schneider Verlag: Esslingen, 298 p.

Bolstad, R., Gilbert, J., McDowall, S., Bull, A., Boyd, S., Hipkins, R., 2012: Supporting future-oriented learning and teaching: ANew Zealand perspective (Report prepared for the Ministry of Education). Wellington, New Zealand: Ministry of Education. 
Britto, P. R., 2017: Early Moments Matter for every child [online]. Published by UNICEF 3 United Nations Plaza, New York, NY 10017, US, Available on: https://www.https://www.unicef.org/media/ files/UNICEF_Early_Moments_Matter_for_Every_ Child_report.pdf.

Cornell, J., 1991: Mit Kindern die Natur erleben. Mülheim an der Ruhr, Verlag an der Ruhr, 147 p.

Cornell, J., 1998: Sharing Nature With Children. Nevada City, Dawn Publications, 216 p.

Devall, B., Sessions, G., 2007: Deep Ecology: Living as if Nature Mattered. Layton, Utah, Gibbs Smith Publishing, $269 \mathrm{p}$.

Dieblová M., 2005: Motivace jako nástroj řízení. Praha, Linde, $127 \mathrm{p}$.

Disman, M., 2002: Jak se vyrábí sociologická znalost. Praha, Karolinum, 374 p.

Dumont, H., Istance, D., Benavides, F., 2010: The Nature of Learning: Using Research to Inspire Practise. OECD Publications.

Emmons, K. M., 1997: Perceptions of the Environment While Exploring the Outdoors: A Case Study in Belize. Environmental Education Research, 3:327-344.

Gavora, P., 2008: Úvod do pedagogického výskumu. Bratislava, Bratislava : Univerzita Komenského, 236 p.

Guskey, T. R., Yoon, K. S., 2009: What Works in Professional Development? Phi Delta Kappan, 90:495-500.

Harkabus, Š., Marušáková, L', 2007:Zásady lesní pedagogiky. In: Učebnice PAWS, p. 64-120.

Hendl, J., 2016: Kvalitativní výzkum: Základní teorie, metody a aplikace. Prague, Portál, 408 p.

Hoyle, E., 2008: Changing conceptions of teaching as a profession: Personal reflections. In: Johnson, D. \& Maclean, R. (eds.): Teaching: Professionalisation, Development and Leadership, New York, Springer Science + Business Media B. V., p. 285-304.

Jickling, B., 2005: Deep Ecology and Education: A Conversation with Arne Naess. In: Naess, A., Drengson, A. (eds.): The Selected Works of Arne Naess. Springer, Dordrecht, 1048.

Kuhlemann, G., Brühlmeier, A., 2002: Johann Heinrich Pestalozzi. Schneider-Verlag., 304 p.

Lai, K. C, Mok, A., Ko, K. W., Li., C., 2001: Issues in Teacher Supply and Retention in England and their Implications for Hong Kong. Teacher Education Planning Digest, 6:1-35.

Liu, E., Kardos, S. M., Kauffman, D., Peske, H. G., Johnson, S. M., 2000: Barely Breaking Even: Incentives, Rewards, and the High Costs of Choosing to Teach. $25 \mathrm{p}$.

Machar, I., 2009: Úvod do ekologie lesa a lesní pedagogiky pro učitele přírodopisu a environmentální výchovy. Olomouc, University of Palacky, 104 p.

Mazáčová, N., 2001: Učitel začátečník. Available on: http://www.ceskaskola.cz/Ceskaskola/ Ar.asp?ARI $=2869 \& C A I=2125$.

Naess, A., 1989: Ecology, community and lifestyle: Outline of an ecosophy. Cambridge, Cambridge University Press, 223 p.
Naess, A., 1993: How Should Supporters of the Deep Ecology Movement Behave in Order to Affect Society and Culture. The Trumpeter, 10:3.

Rickinson, M., 2001: Learners and Learning in Environmental Education: ACritical Review of the Evidence. Environmental Education Research, 7:307-320.

Russell, C. L., 2000: A Report on an Ontario Secondary School Integrated Environmental Studies Programmes. Canadian Journal of Environmental Education, 5:287-304.

Scott, C., Stone, B., Dinham, S., 2001: I love teaching, but... International patterns of teacher discontent. Education Policy Analysis Archives, 28:1-7.

Sinclair, C., 2008: How can what we know about motivation to teach improve the quality of initial teacher education and practicum? In: Towndrow, P.A., Koh, C., Soon, T. H. (eds.): Motivation and practice for the classroom, Rotterdam, Sense, p. 37-61.

Sivek, D. J., 2002: Environmental Sensitivity among Wisconsin High School Students. Environmental Education Research, 8:155-170.

Skibins, J. C., Powell, R. B., Stern, M. J., 2012: Exploring Empirical Support for Interpretation's Best Practices. Journal of Interpretation Research, 17:25-44.

Slaughter, R., 1974: Futures in education. Futures, p. 341-342.

Slee, R., 2001: Social justice and changing directions in educational research: the case of inclusive education. International Journal of Inclusive Education, p. 167-177.

Spear, M., Gould, K., Lee, B., 2000: Who Would be a Teacher? A Review of Factors Motivating and Demotivating Prospective and Practising Teachers. Slough, UK, National Foundation for Educational Research, $83 \mathrm{p}$.

Stern, M. J., Powell, P., Ardoin, N., 2010: Evaluating a Constructivist and Culturally Responsive Approach to Environmental Education for Diverse Audiences. Journal of Environmental Education, 42:109-122.

Stern, M. J., Powell, R. B., Ardoin, N., 2008: What Difference Does It Make? Assessing Outcomes from Participation in Residential Environmental Education Programmes. Journal of Environmental Education, 39:31-43.

Švaříček, R., Šed'ová, K., 2007: Kvalitativní výzkum v pedagogických vědách. Prague, Portál, 384 p.

Tilden, F., 1957: Interpreting Our Heritage. Chapel Hill: University of North Carolina Press, 191 p.

UNESCO, 1978: Final Report Intergovernmental Conference on Environmental Education, Tbilisi, USSR, 14-26 October 1977. Paris: UNESCO

Wedlichová, I., 2011: Emoční inteligence. Ústí nad Labem, Univerzita J. E. Purkyně, 128 p.

Wengraf, T., 2001: Qualitative Research Interviewing: Biographic Narrative and Semi-Structured Methods. London, Sage, 424 p. 